PIOTR KULIGOWSKI

https://orcid.org/0000-0002-6251-0482

Department of History,

Adam Mickiewicz University in Poznań

Centre de recherche en histoire européenne comparée, Université Paris-Est Créteil

\title{
THE PATHOGENESIS OF THE PUBLIC SPHERE IN EXILE: ANARCHY AND UNITY IN THE POLITICAL THOUGHT AND MENTALITY OF THE GREAT POLISH EMIGRATION*
}

Abstract: The post-1831 Great Emigration created conditions that were particularly favourable for the development of Polish political thought. This development, however, would have progressed at a considerably slower tempo without the deepening of ideopolitical differences, which put paid to any belief that the émigrés would reach unity. Paradoxically, successive rifts were often justified exactly by the aspiration to implement the concept of 'unity'. The present article focuses on an issue-based analysis of the tensions between the categories of 'unity' and 'anarchy', and discusses the mechanism which led to the emergence of the public sphere in exile.

Ke y w ords: anarchy, Paris, public sphere, the Great Polish Emigration, unity.

In many parts of Europe, the turn of the nineteenth century may be considered as the period of development of civic spheres of discussion and discourse which were autonomous with respect to the authorities. Very often, the topics of such debates were seemingly apolitical, focusing on issues such as art or morality. Ultimately, however, the very fact that they were being held turned out to have a political effect, for it led to the creation of public spheres with which officialdom increasingly had to reckon. These processes, as is the case with the majority of historical phenomena, were not linear in nature, and depending on context had completely different courses and dynamics.

One of the objectives of the present article is to trace the process of emergence of the public sphere in exile following the collapse of the November Uprising of 1830-31. Two key concepts derived from the political language of the age - 'unity' and 'anarchy' - serve to bring order

* The present work has received support from the Polish National Science Centre (NCN; UMO-2018/28/T/HS3/00023). 
and organization to our deliberations. As some researchers have pointed out, this pair of opposing categories, based on the principle of 'discordia/concordia', had already played an important role in the discourse of European humanist historiography in the sixteenth century. ${ }^{1}$ An important stage in the reconceptualization of the dyad was the French Revolution. Namely, the leading proponents of this act of social upheaval, such as Emmanuel-Joseph Sieyès, soon put forward the concept of 'unity of the nation', with the nation being defined as a political community from which - in the name of unity exactly - one had to exclude the aristocracy. ${ }^{2}$ This notion was subsequently developed by the early socialists, such as Henri de Saint-Simon and Charles Fourier, who drew their visions of unity from, respectively, the organicistic concept of society and the extrapolation of the presumed unity of nature to social life. ${ }^{3}$ Thus, it was not only in the Polish context that the category of 'unity' became one of the key points of reference in political discourse at the beginning of the nineteenth century.

During the period of the Great Emigration the concepts of 'unity' and 'anarchy' created a conceptual space within which the émigrés legitimized their political initiatives and in various ways justified either the unificationist stance, or the separateness of their own political groupings from the rest of the community. Unity of thought and action was usually understood as a precondition of effective political practice, which itself was to lead to the fulfilment of the emigrants' metaphysical mission. This mission was viewed as consisting not only in bringing about the overthrow of the existing geopolitical order that had been established at the Congress of Vienna in 1815, but also in building permanent peace and ensuring the freedom of the peoples of Europe. Anarchy - sometimes defined as dissolution, chaos, or simply disorder - was frequently considered a vestige of the old Polish-Lithuanian Commonwealth. Thus, it was seen as a by-product of the emergence of a space for discussions in which various actors formed distinct arguments, presented differing objectives, and also identified their opponents and allies in specific ways.

${ }^{1}$ Balázs Trencsenyi and Márton Zászkaliczky, 'Towards an Intellectual History of Patriotism in East Central Europe in the Early Modern Period', in Whose Love of Which Country? Composite States, National Histories and Patriotic Discourses in Early Modern East Central Europe, ed. iidem, Leiden and Boston, 2010, pp. 1-72 (pp. 10-11).

${ }^{2}$ William H. Sewell, Jr., A Rhetoric of Bourgeois Revolution: The Abbé Sieyes and 'What is the Third Estate?', Durham, NC, 1994.

${ }^{3}$ Olivier Perru, 'Le concept d'association et l'unité politique: étude critique chez Saint-Simon, Fourier et Marx', Philosophiques, 26, 1999, 1, pp. 83-108. 
The terminology used in the title of present article requires both precising and substantiation. The titular concept of 'pathogenesis' was introduced to historical analysis by Reinhart Koselleck, who viewed it as a metaphorical depiction of the appearance of the bourgeois public sphere. The German scholar provocatively adopted this category, of key importance for his research, from medical terminology, in which pathogenesis simply refers to the manner of development of a disease. Koselleck went on to state that seemingly apolitical actions - meetings in salons, business firms, or literary societies - led to the institutionalization of the enlightened intellect, and from there to the negation and ultimate destruction of the absolutist state from within. ${ }^{4}$ To a certain degree, a parallel mechanism functioned in emigrant circles, where the struggle for the right to represent the émigré community (or even the entire Polish nation) resulted in the development of a host of new political ideas and concepts. Nevertheless, another effect of this mechanism was the permanent infection of the emigrant body with the virus of political discord and division, which only served to intensify the longing for unity - never brought to fruition, but incessantly desired. ${ }^{5}$

Agreeing with Koselleck's findings, I understand the public sphere in exile, the emergence of which accompanied the advent of rival groupings and factions, as being the space for political thought, discussion and practice. A characteristic feature of this space is the possibility of participating in it through the medium of dialogue (mainly through journalistic articles in the case of the Great Emigration), and not - for example - violence. ${ }^{6}$ But by no means should this be understood as meaning that the émigrés did not use violence: extant writings describe at least several dozen instances of physical assaults and duels. However, the steady improvement in printing techniques, and also the relatively broad scope of freedom of speech in Western Europe (especially when compared with the Russian partition zone of Poland), resulted in the vast majority of disputes being

\footnotetext{
${ }^{4}$ Reinhart Koselleck, Kritik und Krise: Eine Studie zur Pathogenese der bürgerlichen Welt, Frankfurt am Main, 1973.

${ }^{5}$ Maria Janion, 'Estetyka średniowiecznej północy', in eadem, Prace wybrane, 5 vols, ed. Małgorzata Czermińska, Cracow, 2000-02, vol. 4: Romantyzm i jego media, 2001, pp. 7-88 (pp. 68-73).

${ }^{6}$ Nancy Fraser, 'Rethinking the Public Sphere: A Contribution to the Critique of Actually Existing Democracy', Social Text, 1990, 25/26, pp. 56-80 (p. 57); Monika Baár, Historians and Nationalism: East-Central Europe in the Nineteenth Century, Oxford, 2010, p. 132; Wiktor Marzec and Kamil Śmiechowski, 'Pathogenesis of the Polish Public Sphere: The Intelligentsia and Popular Unrest during and after the 1905 Revolution', Polish Sociological Review, 2016, 4 (196), pp. 437-57 (p. 437).
} 
conducted through argumentation. These polemics allowed individual actors to express themselves more fluidly and effectively - the political discourse developing in France, for example, provided people with tools for articulating their reflections in fields which had hitherto been less accessible to Polish thought (such as the issue of the workers), while the Parisian radicals made public opinion familiar with their bold critique of the monarchy and the Church.

But the development of the public sphere within the Polish emigration after 1831 was not free of visible ambivalences. For while the mission of the emigrant community was to consist in a reflection on the factors which had brought about the collapse of the Polish state and a search for effective methods of its reconstruction, its execution was accompanied by vehement disputes, which Adam Mickiewicz so tellingly dubbed 'the hellish quarrels' (a quotation from the epilogue to the poem Pan Tadeusz (Sir Thaddeus), 1834). Thus, in the metapolitical dimension the intellectual approach of Polish émigrés to the public sphere which had been created within their milieu was organized using the opposing concepts of 'unity' and 'anarchy', with the latter having decidedly negative connotations. This led to the development of the situation described among others by Koselleck, wherein an attempted negative classification of political opponents formulated by certain actor was accompanied by proposing a new positive label in reference to his (or her) own community. The positive label, claimed Koselleck, was in a number of cases grounded in universalistic categories, whereas political opponents were depicted as expounding only narrow particular interests. ${ }^{7}$ In other words, practically each emigrant political milieu attributed 'unity' to itself, and the propensity for discord and anarchy to its opponents.

In order to realize the objectives of the study, I have broken down my disquisition into four fundamental parts. The first serves to present the context in which the Polish émigrés functioned. Obviously, one of its most important and challenging elements was the historical experience of the Polish-Lithuanian Commonwealth, which they therefore attempted to dissect and analyse within the framework of their political activity. The next section outlines the reactions of emigrant circles to the emergence of rival groupings, which through their bitter mutual attacks created barriers between the exiles, thus thwarting any remaining hopes for joint action being undertaken in Western Europe for the purpose of liber-

${ }^{7}$ Reinhart Koselleck, 'Zur historisch-politischen Semantik asymmetrischer Gegenbegriffe', in idem, Vergangene Zukunft: Zur Semantik geschichtlicher Zeiten, Frankfurt am Main, 1995, pp. 211-59. 
ating Poland. The circles gathered primarily (although not exclusively) around Prince Adam Jerzy Czartoryski viewed Paris as the source of 'anarchy', and democrats as the carriers of this 'pestilence'. Certain accounts indicate that the latter, by spreading their beliefs among emigrants resident in various other cities and townships, fomented quarrels which on a number of occasions ended in duels. These developments led to a redefinition of the concept of 'anarchy' itself. The third part discusses the concepts of unification which emerged in consequence of debates conducted within the majority of émigré groupings. The fourth and final section contains an analysis of the discourse evolved by the democrats, with particular focus on a singularly important source, namely the rich body of correspondence sent in to the Temporary Committee of the Polish Emigration between January and May 1862. The establishment of the Committee marked the beginning of one of the most serious and at the same time realistic attempts at unifying the Polish emigrant community, but while many of the abovementioned communications contain highly enthusiastic declarations of accession to the organization, numerous others show considerable hesitation and ambivalence. In concluding, I will describe the long-term impact of the phenomena presented in the study for Polish political thought.

\section{The Pathogenesis: The Ideological Structures} of the longue durée

The public sphere in exile developed within the framework of a specific system of political notions which had been shaped over centuries. Its key elements were political mentality, the sphere of concepts, and - finally notions that could be invoked in the course of disputes. While it is true that the Great Emigration's perceptive imagination was characterized by a dynamic of modernization previously unheard of in Polish political life, its discourse can be found to contain completely unobvious or even unexpected references to earlier periods. An interesting example of the muddled ideological structures of the 'long continuance' was the approach taken by some activists towards the principle of liberum veto. For example, Ludwik Królikowski - a radical opponent of 'gentility' (taken to mean the generality of traits and customs typical of the Polish nobility (szlachta), along with the specific political system which it developed) - defended this parliamentary device in his book. ${ }^{8}$ The existence of such long-term structures

${ }^{8}$ Ludwik Królikowski, Do panślawistów: pogłos z odwiedzin niby sławiańskich w Moskwie 1867 roku, part 1, Zurich, 1868-74, p. 337. 
requires at least a brief description of the fundamental traits of political thinking typical of the old Commonwealth, and also of the Enlightened attempts at breaking free of the existing political mould.

It would appear that the model of political life and system of the Polish-Lithuanian Commonwealth had no exact equivalents in the countries of Western Europe. Whereas the singular features of the form of government with which the émigrés had to contend at the level of historiographical deliberations in the wake of the November Uprising (1830-31) were the advent of the political nation, the development of the concept of interclass equality amongst the nobility, and the contractual system of authority. The latter in particular became the focus of reflection of the Polish exiles, who attempted a critical redefinition of the problem of the old szlachta's fear of the absolutum dominium and more broadly - of the issue of the right to legally renounce allegiance to one's king. ${ }^{9}$ Many historiosophers and thinkers of the Great Emigration viewed this state of affairs as one of 'the nobles' anarchy', and regularly considered it as the main cause of the partitions. For example, the historian Joachim Lelewel was very critical in his appraisal of how the nobility governed during periods of interregnum; in his opinion, this had led to lawlessness and a weakening of the country. ${ }^{10}$ To put it succinctly, the old Commonwealth was perceived intuitively as a country that was actually made up of many homelands and many neighbouring realms of sovereignty, in which the private and public orders

${ }^{9}$ Anna Grześkowiak-Krwawicz, 'Anti-monarchism in Polish Republicanism in the Seventeenth and Eighteenth Centuries', in Republicanism: A Shared European Heritage, ed. Martin van Gelderen and Quentin Skinner, 2 vols, Cambridge, 2002, vol. 1: Republicanism and Constitutionalism in Early Modern Europe, pp. 43-60; Andrzej Walicki, Philosophy and Romantic Nationalism: The Case of Poland, Oxford, 1982, pp. 4-27.

10 'Skłonność szlachty do swawoli najbardziej się pokazała w czasie szybko nadchodzących po sobie bezkrólewi. Wtedy w skoki szlachta dokazywać poczęła, cieszyła się, że można hukać, pukać, bo nikogo nie było, co by ją upomniał. Wtedy jakby rozum stracili, dopuszczali się złego, krzywdzili, popełniali gwałtowności, a co w ciągu wielu lat w Rzeczypospolitej naprawionego było, to w kilku miesiącach bezkrólewia popsuli. Ale i w ciągu panowań królów swoich dopuszczali się swawoli' ('The nobility's propensity for insubordination became most evident during the interregnums, which soon began occurring in rapid succession. The nobility would immediately start frolicking, happy that they could bawl and bellow to their hearts' content, for there was no one to admonish them. It was as if they had lost their minds, committing bad deeds, wronging others, and generally letting their hot-headedness get to the fore, so that that which over many years of existence of the Commonwealth had been repaired, they successfully destroyed during a few months of interregnum. But their behaviour was also marked by insubordination even when kings reigned'), Joachim Lelewel, Dzieje Polski potocznym sposobem opowiedziane, ed.Janina Bieniarz, Warsaw, 1961, p. 147. 
intertwined with each other. ${ }^{11}$ As it transpired, this intermingling was also one of the ideological structures of the 'long continuance', and manifested itself in some of the arguments formulated as part of the broader analysis of the organizational structure of émigré life.

Thus, the Polish reformatory movement of the Enlightenment was faced with different tasks than its Western European equivalents. For the advocates of reform in the Commonwealth were striving not to undermine absolutism, but to strengthen central authority. A singular novelty in this context was the emergence in the final decades of the eighteenth century of the concept of the state interpreted in abstract categories, that is as an institution extraneous to its citizens, and not - as had been the case previously - as a monarchic reign (therefore the term 'the states [provinces] of the Commonwealth' was logically coherent and very apt). Not without reason did the concept of the Commonwealth substantially disappear from the Enlightened debate on modernization; as a matter of fact, it was not mentioned even once in the Constitution of 3 May (1791). It was symptomatic that in the disputes of the times advocates of reform and the strengthening of central authority considered that the nobles anarchy could be effectively curbed using the very same measures which were perceived by their opponents as a threat to freedom. ${ }^{12}$ The Enlightened modernization of political language and mentality was halted by the partitions, although in all probability a part of the contemporary political elites had a clear problem with understanding the significance and consequences of the event. Specifically - and this has been pointed out by researchers - the historical discourse of the nobility used the categories

${ }^{11}$ Modern researchers, too, hold widely different interpretations of this 'intermingling'. Suffice it to mention that in his collection of essays, provocatively entitled Polska anarchia, the writer and historian Paweł Jasienica argued that the old Commonwealth did not collapse because of the anarchic actions of the middle and lesser nobility. To the contrary, he for one was inclined to look for the causes of the partitions in the abuses of power committed by influential individuals (idem, Polska anarchia, Warsaw, 2008; 1st edn 1988). A diametrically opposite standpoint has been presented by Jan Sowa, who opined that following the death of King Sigismund II Augustus the state had practically ceased to exist, while the power of the nobility was fated to collapse from the very beginning (idem, Fantomowe ciało króla: Peryferyjne zmagania z nowoczesna forma, Cracow, 2011).

12 Balázs Trencsényi, 'Conceptual History and Political Languages: On the Central-European Adaptation of the Contextualist-Conceptualist Methodologies of Intellectual History', in The History of East-Central Europe and Russia, ed. Petr Roubal and Václav Veber, Prague, 2004, pp. 142-63, Prague Perspectives, vol. 1; Anna Grześkowiak-Krwawicz, 'Spór o “Ustawę rządową” jako zderzenie dwóch dyskursów politycznych?', Wiek Oświecenia, 31, 2015, pp. 195-212; Balázs Trencsenyi et al., A History of Modern Political Thought in East Central Europe, 2 vols, New York, 2016-18, vol. 1: Negotiating Modernity in the 'Long Nineteenth Century', p. 28, 42. 
of sovereignty, statehood and independence in meanings which made it difficult to confront the fact of the disappearance of the Commonwealth as a sovereign polity. ${ }^{13}$

It is very likely that such an understanding of state sovereignty, incomplete and difficult to articulate through the contemporary conceptual apparatus, was one of the reasons why the 'old' were unable to come to an agreement with the 'young' on the eve of the November Uprising. After all, during the first few hours of the revolt the young conspirators killed six generals not because these men had announced that they would undertake any countermeasures, but for simply refusing to take part in the Rising. ${ }^{14}$ In a symbolic sense, this development marked the beginning of a new division in Polish public life. And so on the one hand there gradually came to prominence a generation of young journalists and military men who questioned established authorities and called for a social revolution; importantly, therefore, they aspired for their 'revolution' to be something more than just an armed rising of the nobility that would be in keeping with the class tradition of resistance to authority. ${ }^{15}$ Whereas on the other, the generals - aiming to bridle the radicals - started to use the catchwords of 'concord' and 'unity'. ${ }^{16}$ Following the collapse of the Uprising, many soldiers crossed the Prussian-Austrian border (some 50,000 people were interned) ${ }_{1}^{17}$ and then started to move, wave after wave, to various countries of Western Europe. Many of them were convinced that in a few months, in any case no later than after two or three years, they would return home in triumph, vanquishing their foes. Having found themselves in exile, the insurrectionary elites strove to recreate the institutions that had functioned during the Uprising, among others the Sejm, which was to operate as the supreme authority of the emigrant milieux.

During the first few years after the collapse of the Insurrection, some 8,000-9,000 people were forced into exile for political reasons; ${ }^{18}$

${ }^{13}$ Maciej Janowski, 'Rozpacz oświeconych? Przemiana polskiego języka politycznego a reakcje na upadek Rzeczypospolitej’, Wiek Oświecenia, 25, 2009, pp. 29-60.

${ }^{14}$ Alina Witkowska, Wielkie stulecie Polaków, Warsaw, 1987, p. 14.

${ }^{15}$ Janowski, 'Rozpacz oświeconych?', p. 48.

${ }^{16} \mathrm{Cf}$. Władysław Zajewski, Walki wewnętrzne ugrupowań politycznych w powstaniu listopadowym 1830-1831, Gdańsk, 1967, passim.

${ }^{17}$ Lubomir Gadon, Emigracya Polska: Pierwsze lata po upadku powstania listopadowego, 3 vols, Cracow, 1901-02, vol. 1, pp. 7-8; Helmut Asmus, 'Trasy przemarszu wychodźców polskich po upadku powstania listopadowego przez państwa niemieckie do zachodniej Europy', Przeglad Humanistyczny, 26, 1982, 3/4, pp. 1-24 (p. 5); Norbert Kasparek, Powstańczy epilog: Żołnierze listopadowi $w$ dniach klęski i internowania 1831-1832, Olsztyn, 2001.

${ }^{18}$ Jakub Malinowski, 'Rzut oka na Emigracyą Polską pod względem literackim, naukowym i technicznym od roku 1832 do 1848 ', BJ, MS 3010, p. 9; Adam Lewak, 'Czasy 
when viewed over a somewhat broader time frame, specifically the period 1831-62, this estimate comes close to $20,000 .{ }^{19}$ The decided majority of Polish émigrés travelled to France, and by 1846 there were nearly 5,000 Poles in the country; ${ }^{20}$ in comparison, during the entire period from 1830 to 1870 only slightly more than 1,000 Polish political exiles made their way to Belgium, while between 1831 and 1862 no more than 2,600 journeyed to Great Britain. ${ }^{21}$ Viewed as a whole, this essentially small community soon became recognized for its prodigious political, literary and journalistic activity. Surviving estimates indicate that during the 30 years of its existence, the Polish Democratic Society (1832-62) had more than 4,000 members in total, while during the peak of its popularity there were in excess of 1,500 emigrants in its ranks. ${ }^{22}$ If we take into consideration the fact that in 1840 the moderate and fundamentally centrist United Polish Emigration had more than 2,000 members ${ }^{23}$ and further that the grouping of Prince Adam Jerzy Czartoryski also had numerous supporters (in 1834, the act of loyalty to the Prince was signed by 2,840 persons) ${ }^{24}$ it becomes clear that the decided majority of émigrés actually expressed their political opinions in one way or another, and professed their sympathy for various of the existing groupings.

The far-reaching politicization of opinion also influenced the development of specific practices of public life, accompanied as it was by the establishment of political associations, committees and societies on a scale unprecedented in Polish history (as a matter of fact, forty or so such organizations were established in the years 1831-62). During the very same period, Polish émigrés also set up several dozen scientific, educational, religious, military, artistic and cultural institutions ${ }^{25}$ This process was accompanied by an outpouring - again, unparalleled in the Polish context - of journalistic and other writings. According to calculations made by Jakub Malinowski, exactly 562 books and brochures (the latter numbering several

Wielkiej Emigracji', in Polska, jej dzieje i kultura, ed. Stanisław Lam, 3 vols, Cracow, [1929-32], vol. 3, pp. 193-233 (p. 199).

${ }^{19}$ Sławomir Kalembka, Prasa demokratyczna Wielkiej Emigracji: Dzieje i główne koncepcje polityczne (1832-1863), Toruń, 1977, p. 14.

${ }^{20}$ Malinowski, 'Rzut oka na Emigracyą Polską', p. 9.

${ }^{21}$ Idesbald Goddeeris, La Grande Émigration polonaise en Belgique (1831-1870): Élites et masses en exil à l'époque romantique, Frankfurt am Main, 2013, p. 45; Krzysztof Marchlewicz, Wielka Emigracja na Wyspach Brytyjskich (1831-1863), Poznań, 2008, pp. 24-26.

${ }^{22}$ Marian Tyrowicz, Towarzystwo Demokratyczne Polskie, 1832-1863: Przywódcy i kadry członkowskie: Przewodnik biobibliograficzny, Warsaw, 1964, p. IX.

${ }^{23}$ Bogusław Cygler, Zjednoczenie Emigracji Polskiej 1837-1846, Gdańsk, 1963, p. 74.

${ }^{24}$ Henryk Żaliński, Poglądy Hotelu Lambert na kształt powstania zbrojnego (1832-1846), Cracow, 1990, p. 54.

${ }^{25}$ Kalembka, Prasa demokratyczna Wielkiej Emigracji, p. 15. 
dozen or so pages each) written by Poles or - to a lesser extent - by sympathizers of the Polish cause in Polish, French, English, Italian and German were published in Western Europe in the years 1830-48 alone. ${ }^{26}$ Furthermore, between 1831 and 1863 the emigrant milieux printed a total of 150 journals, ninety-three of which in Paris. ${ }^{27}$ These data illustrate the scale of geographical unevenness of émigré literary output. It was for good reason, therefore (and I shall go into detail on the topic further on in the study), that Paris was considered as the epicentre of emigrant discord. But what strikes us when analysing these numerical data is not just the concentration of political life itself in the French capital, but also the copious amount of journalistic writings which it engendered. Władysław Mickiewicz was very much right when he wrote in his memoirs that he was unable to find amongst the Polish émigrés even a single person who had not written at least one small article or political appeal. ${ }^{28}$

On the basis of the information cited above we may state that the practices of political life developed by the Great Emigration were a novel quality in Polish history. Phenomena of a similar scale had not evolved during earlier mass emigrations brought about by the collapse of the Bar Confederation (1772) or the Third Partition of Poland (1795). Despite certain limitations of the freedom of speech, which were often the result of both legal measures (for example the introduction of a restrictive press law in France in 1835) and insufficient financing, Polish emigrants engaged themselves in political debates and also absorbed a number of new concepts and forms of political thinking. The situation brought into being by the defeat of the Uprising and the overall condition of the emigrants implied, on the one hand, the necessity of determining who was at fault for their predicament, while on the other - of formulating a credible route of action that would take the former soldiers forward. This created a basis for political division and strife, which followed rapidly.

\section{The Disease: The Democratic Pestilence and Parisian Anarchy}

Nearly immediately after the collapse of the Uprising, on 6 November 1831, the Temporary Committee of the Polish Emigration was formed in Paris. The Committee's self-determined mission was to organize aid for

\footnotetext{
${ }^{26}$ Malinowski, 'Rzut oka na Emigracyą Polską', pp. 37-38.

${ }^{27}$ Władysław Marek Kolasa, 'Prasa Wielkiej Emigracji (1832-1870) w polskim prasoznawstwie', Zeszyty Prasoznawcze, 56, 2013, 3, pp. 389-400 (pp. 390-91).

${ }^{28}$ Quoted after Bronisław Baczko, Poglady społeczno-polityczne i filozoficzne Towarzystwa Demokratycznego Polskiego, Warsaw, 1955, p. 158.
} 
Poles who found themselves in exile and provide them with government-based assistance. It is very important to note that its founders did not make any far-reaching political demands, being convinced that in order to engage in politics, one really ought to be in the homeland. Soon, however, the elected authorities of the Committee met with resistance. Adam Gurowski and Maurycy Mochnacki published brochures in which they pointed out that the body was headed by persons who had led the November Uprising to its collapse..$^{29}$ Mochnacki - and we must view his interpretation as symptomatic - made use of the rhetoric of unification in order to substantiate the necessity of questioning the very existence of the Committee in its then form. He wrote that only by challenging the authority of the 'Kalisz grouping' (a loose association of liberal politicians from the Kalisz Palatinate, active in the years 1820-31) and supporting persons such as Lelewel would it be possible to head off émigré disputes once and for all. ${ }^{30}$ Due to growing internal opposition, the Committee dissolved itself already on 8 December 1831.

A week later, on 15 December, the Polish National Committee was established. This body included a number of radicals who had formed a far-reaching programme of social reform already during the Uprising. The new Committee was to be elected by the so-called Parisian Generality, of which everyone who signed the instruments of the Committee could be a member. ${ }^{31}$ Already the first appeal published by the Polish National Committee, on 25 December 1831, contained a strong accusation against the former leaders of the Uprising, charging them directly with treason. ${ }^{32}$ General Józef Bem knew very well what he was saying when he declared that assemblies of the Parisian Generality were attended by a group created through the 'marriage of "Honoratka" with Jacobinism'..$^{33}$ This was a reference to the 'Honoratka' café in Warsaw, which during the Uprising had been a popular meeting place for those demanding that the insurrectionary authorities take decisive military action and introduce far-reaching social reforms. Thus, at the very beginning of the Great Emigration the opponents of Polish democratic groupings viewed the French capital as a hotbed of discord and anarchy, while it soon turned out that the idea

${ }^{29}$ Gadon, Emigracya Polska, pp. 123-24.

30 'you will put a final end to the internal discords which shall otherwise tear us asunder as long as the politicians from Kalisz influence the council.' Maurycy Mochnacki, Do Rodaków bawiących w Paryżu przeciw Komitetowi Tymczasowemu Emigracji Polskiej, Paris, 1831, p. 6.

${ }^{31}$ Gadon, Emigracya Polska, pp. 127-28.

${ }^{32}$ Ibid., pp. 127-31.

33 Jan Kucharzewski, Maurycy Mochnacki, Cracow and Warsaw, 1910, p. 333. 
that the emigrants would undertake action jointly was considerably more difficult to implement than had previously been thought.

The first pamphlets and heated debates, the latter held mainly in the meeting hall of the Hotel Taranne in Paris, acted upon the émigré organism like a pathogen and rapidly led to the creation of political divisions within the community, hitherto cemented by the experience of the Uprising. On 17 March 1832, following a series of disputes within the Polish National Committee, there emerged the Polish Democratic Society, which adopted the so-called Small Manifesto - first and foremost a programme of negativity. Initially, its membership developed slowly: on 19 August 1832 there were only 45 surnames on its roll, and 101 on 16 January $1833 .{ }^{34}$ With time, however, the radicals gained a steadily stronger influence over the emigrants, who were very receptive to left-wing catchwords and mistrusted the 'aristocratic system'. Their susceptibility to leftist ideas was due at least in part to the fact that French and German milieux of similar political leanings were most favourably inclined towards the post-November émigrés. It is worth citing one very characteristic example: during the Uprising the journal of the 'French revolutionary Catholics', which was published by Hugues Félicité Robert de Lamennais and viewed the Poles fighting against tsarism as active propagators of Catholicism, printed as many as 370 texts devoted to the Polish cause. ${ }^{35}$

The emergence of the democratic grouping, which intended to build its separateness not on loyalty to a specific person or the nobles' family (as was later the case with the followers of Czartoryski, Andrzej Towiański and Maciej Rybiński), but on a specific 'political faith', marked the emergence of the public sphere in the full meaning of the term. The establishment of the Polish Democratic Society, coupled with the collapse of three successive military campaigns (the Frankfurt expedition, the Savoy expedition, and the failed attempt at fomenting an insurrection in the Russian partition zone in 1833, known as Zaliwski's partisan expedition), significantly influenced and hastened the process which Adam Lewak called the transformation of emigrant-soldiers into emigrant-politicians. Nevertheless, and this he stressed with considerable aptness, the trans-

34 Sławomir Kalembka, Wielka Emigracja: Polskie wychodźstwo polityczne w latach 1831-1862, Warsaw, 1971, p. 116.

35 Gaston Bordet, La Pologne, Lamennais et ses amis 1830-1834, Paris, 1985, p. 37; Sylvain Milbach, 'Perspectives catholiques sur la révolution: L'Avenir de Lamennais', in Quand les socialistes inventaient l'avenir: Presse, théories et expériences, 1825-1860, ed. Thomas Bouchet et al., Paris, 2015, pp. 62-74 (p. 70). 
formation was first experienced by those who had settled in Paris. ${ }^{36}$ In April 1833, Lelewel had good cause to write emphatically that "Anarchy reigns in Paris'. ${ }^{37}$

The disputes carried on in Paris during the first dozen or so months of the emigration were not fully understandable for those who lived outside the French capital, in the so-called dépôts - institutions set up by the French government to maintain military discipline among the exiles. These centres, and following their dissolution in 1833 also the smaller associations of Poles (sometimes grouping no more than a few people), created their own Generalities, which according to the plans of the émigré authorities in Paris - at the time awaiting formalization of their existence - were to fulfil a role similar to that of the regional councils in the old Commonwealth. The objective was to mould the emigration into a federative body within which the decisions of the centre would have to be approved by local gatherings of Poles. However, it rapidly became obvious that this structure of functioning of the Polish political emigration would be very difficult to implement. Numerous attempts at appointing a supreme representative authority for the émigrés ended in fiasco, being derailed by personal ambitions and deepening ideological rifts.

For those Poles who were insufficiently informed about the Parisian quarrels, the disputes and divisions were a source of disorientation. Shortly after their arrival in France and the establishment of their own Émigré Council (an equivalent of the Generality), the exiles in Châteauroux dispatched a letter to Jan Nepomucen Janowski - a man excellently oriented in the quarrels taking place in Paris - and directly expressed their wish to join the unified emigrant milieu. However, the Council of Châteauroux inquired why these circles had still not issued a joint 'organic act' outlining the general objectives of action..$^{38}$ Ultimately, such an act was never drawn up, and the emigrant circles experienced further splits.

Extant source materials allow us to at least partially reconstruct the reactions of those who did not reside in Paris or were not directly involved in the ideological disputes to the fact of emergence of the public sphere in exile. Adam Szablicki in his text entitled 'Klęska Narodu' (The Tragedy of a Nation), which never appeared in print, wrote that shortly after the appearance of Polish emigrants in France the émigré political

${ }^{36}$ Lewak, 'Czasy Wielkiej Emigracji', pp. 202-03.

${ }^{37}$ Joachim Lelewel's letter to Walenty Zwierkowski, 27 April 1833, in Listy emigracyjne Joachima Lelewela, ed. Helena Więckowska, 5 vols, Cracow, 1948-56, vol. 1: 18311835 (Nry 1-289), p. 131.

${ }^{38}$ The Council of Poles in Châteauroux to Jan Nepomucen Janowski, 16 January 1832, BJ, MS 3686, fol. 6. 
scene became rife with avowed advocates of completely different political concepts. ${ }^{39}$ Szablicki was under no illusion as to who was responsible for this state of affairs - 'the destructive pestilence of Jacobinism' had seized the minds and introduced 'anarchy'. ${ }^{40}$ Another important source for tracing the reactions of run-of-the-mill exiles to the ideological and organizational divisions occurring within the Polish diaspora are the fragmented memoirs of Józef Alfons Potrykowski. Their author referred to the editors of Nowa Polska - a journal which frequently published particularly sharp satires aimed against important persons from the emigrant community as 'fervent anarchists'. But when speaking about the members of the Polish Democratic Society, Potrykowski consistently used the terms 'patent-holder' or 'registered' democrats. These descriptors were uniformly negative, for they suggested that the politicians to which they referred held a 'patent' or an exclusive right to certain concepts and voiced them with some degree of exaggeration. Thus, Potrykowski implied that such open admittance of one's specific political affiliation was not yet typical of Polish political life. ${ }^{41}$ In November 1833, he observed that the political disputes were heating up due to the emergence of the democrats, who were ready to promote their ideas without any compromise. Potrykowski stressed that these quarrels were generating hatred between the émigrés. ${ }^{42}$ Whereas on 1 January 1834, displaying a clear aversion to the changing practices of public life, he mentioned in his memoirs a 'feast' that had been organized by the democrats; this deteriorated into the loud discussions that he considered highly typical of the representatives of this part of the political scene. ${ }^{43}$

39 'the supporters of different faiths, different concepts and different colours'.

${ }^{40}$ Adam Szablicki, 'Klęska Narodu', BC, MS 5314, pp. 27, 51-52.

${ }^{41}$ Józef Alfons Potrykowski, Moje notatki oraz bez dat urywki 1832, 1834, 1836 i 1848, BC, MS 5349, pp. 38, 42.

42 'Cały ten miesiąc nie był zaszczytnym dla Polaków samych ani przyjemnym dla naszego pożycia. Kłótnie i swary po żwawych i dotkliwych dysputach wiele chwil zabierały: opinie najzjadliwsze pod maską Demokracji ukryte wydały się przez propagandzistów i to co sprawiło w duszach stałych obmierzłość nawet samą nienawiść dla tych chytrych interesantów' ('This entire month has been neither honourable for us Poles, nor pleasant for our social life. Spirited but at once painful discussions, followed by quarrels and strife, consumed much time: propagandists have presented the most spiteful opinions under the guise of Democracy, and by their actions generated a hatred for the cunning intriguers which they indeed are in even the most good-natured and steadfast of souls.'), ibid., p. 44.

43 'Wieczorem w Kabarecie u Bissona gdzie dużo się stołuje naszych ziomków, była biesiada przez Demokratów wydawana dla Jana Nepomucena Janowskiego. Podchmieliwszy sobie bardzo dobrze, zaczęli dysputy właściwe swej partii z krzykiem i hałasem zwyczajnym' ('In the evening at Bisson's Cabaret, where many of our com- 
It is interesting to note that echoes of the 'strife' raging in the emigrant community also came to the attention of persons who, although actively involved in politics, had after 1831 decided to remain in the Polish lands. Commenting on the endless discussions and political meanderings, Bibianna Moraczewska wrote that the émigrés passed their lives like students. ${ }^{44}$ Another writer, Andrzej Józefczyk, pointed out that the emigration as such was a 'political church, and this resulted in articles of faith [that is to say 'of political faith', a popular designation for 'world view' in the period - P.K.] reaching Poland'. ${ }^{45}$ We can see, therefore, that the echoes of the quarrels taking place in the Parisian Hôtel Taranne reached far outside the French capital and indeed the country itself, gradually transforming Polish political life.

Initially, the disease of anarchy attacked the Paris-based Committees and the provincial Generalities (General Associations of the Polish Emigration beyond Paris), but over time the 'pestilence' spread far and wide. A telling example of the problem of collapse of unity is the fate of the phantom Emigration Sejm, which was supposed to have been an extension of the institution that functioned during the Uprising. Ultimately, however, its full restoration was never achieved, primarily because of the polarization of opinion on a hitherto unknown scale and along previously unheard-of categories. Czartoryski was sceptical about the very concept of parliamentary assemblies, fearing the dominance of the radicals and a deepening of the divisions already existing in the emigrant community under the influence of parliamentary anarchy. Lelewel, however, was wary of the possible supremacy of Czartoryski's supporters, and started to promote a somewhat vague opinion as to the necessity of establishing a 'Parliamentary Union'. Finally, in 1835, the very advocates of the Sejm-in-exile came to the conclusion that this body would be incapable of accommodating both the adherents and opponents of Czartoryski's policy. ${ }^{46}$

patriots eat, the Democrats hosted a feast for Jan Nepomucen Janowski. Having had a drop too much, they engaged in disputes typical of their party, accompanied by loud shouts and a general commotion'), ibid., pp. 105-06.

${ }^{44}$ Dziennik Bibianny Moraczewskiej, ed. Ludwika Dobrzyńska-Rybicka, Poznań, 1911, p. 13.

${ }^{45}$ Andrzej Józefczyk, Wspomnienie ubiegłych lat (Przyczynek do Historyi Spisków w Galicyi), Cracow, 1881, pp. 19-20.

${ }^{46}$ Walenty Zwierkowski, o Sejmie w emigracyi, Poitiers, 1839; Henryk Żaliński, Stracone szanse: Wielka Emigracja o powstaniu listopadowym, Warsaw, 1982, p. 29; Małgorzata Karpińska, 'Sejm polski na emigracji 1832-1848: Problemy i pytania badawcze', in Wokót powstania listopadowego: Zbiór studiów, ed. Hubert Chudzio and Janusz Pezda, Cracow, 2014, pp. 291-307. 
The ideological polarization finally 'infected' - to use Szablicki's term - even the most symbolic and, as some émigrés may have initially thought, apolitical events, such as the ceremonies held to commemorate important national anniversaries, first and foremost those of the November Uprising. The first scandal occurred already in 1832, when Tadeusz Krępowiecki gave a speech - in French - during which he presented a stinging accusation of the nobility as a social class. ${ }^{47}$ This resulted in Krępowiecki being condemned not only by those who sympathized with the newly developing liberal-monarchist camp, but also by the democrats (and even those democrats who were as radical as Stanisław Worcell). ${ }^{48}$ At the time, Jan Czyński was nearly as uncompromising in his assessment of the massacre which had occurred during the night of 15 August 1831, when a crowd gathered in Warsaw and, dissatisfied with the policy of the insurrectionist authorities, lynched tens of prisoners. Czyński was of the opinion that these acts were not a reprehensible crime, but a just emanation of the voice of the people, that is of the voice of God..$^{49}$ A year later, in 1833 , the celebrations were not marred by any such large a scandal, although clear differences of opinion became apparent between participants. For this reason, joint commemorations of the outbreak of the November Uprising which gathered people of different world views were held on only two occasions. After 1833, individual political groupings organized the events separately, treating them as yet another parade stand from which they could present their own political standpoints. ${ }^{50}$

Further rifts appeared rapidly over the next few years. In 1834, a group of radicals headed by Worcell brought about a split in the London Generality (General Association of the Polish Emigration in London) by gathering around themselves persons inspired by the notion of 'equalization of social conditions', the main postulate of which was the common ownership of land. Shortly after, in 1835, there occurred a split in the Polish Democratic Society: following an internal discussion concerning the issue of ownership, ${ }^{51}$ its Portsmouth and Jersey sections withdrew, setting

47 'Przemówienie Tadeusza Krępowieckiego, wygłoszone w Paryżu 29 listopada 1832 r. w rocznicę rewolucji polskiej’, in Witold Łukaszewicz, Tadeusz Krępowiecki: Żotnierz rewolucjonista [1798-1847], Warsaw, 1954, pp. 148-62.

${ }^{48}$ Jan Nepomucen Janowski, Notatki autobiograficzne 1803-1853, ed. Marian Tyrowicz, Wrocław, 1950, pp. 373-75; Bolesław Limanowski, Stanisław Worcell: Życiorys, Warsaw, 1948, pp. 95-96; Witold Łukaszewicz, Stanisław Gabriel Worcell, Warsaw, 1951, p. 59.

${ }^{49}$ Jan Czyński, Józef Kozłowski, Paris, 1832.

50 Bogusław Cygler, 'Obchody rocznic wybuchu powstania listopadowego na emigracji do 1846 roku', in Powstanie czy rewolucja? W 150 rocznice powstania listopadowego, ed. Henryk Kocój, Katowice, 1981, pp. 287-308 (p. 289).

51 The discussion was written down in Okólniki TDP 1834/1836, particularly pp. 215-42. 
up the Communes of the Polish People ('Grudziąż' and 'Humań' respectively). As an organization, the Communes were inspired by concepts of Christian communism and viewed the peasants as potential implementers of the ideals of common ownership. Soon, however, the Communes too experienced a rift - in 1837 Krępowiecki left the organization and together with tens of supporters set up the Society of Adherents to Social Duties and Responsibilities.

The same year witnessed the establishment of the United Polish Emigration, which was created mainly on the initiative of Lelewel; unfortunately, it did not achieve its set objective, and indeed brought about a deepening of divisions within the émigré community. The milieu centred around Czartoryski had similarly little internal cohesion. Within its ranks, too, there functioned an independent political grouping - the Monarchic Society of the Third of May (in the years 1843-48). It failed, however, to gather all of the Prince's supporters, and actually caused friction within the liberal-monarchic camp. ${ }^{52}$

First-hand observance of these phenomena led to a reconceptualization of the concept of anarchy, which soon gained a few more basic meanings in the émigré discourse. On the one hand, it began to be used to criticize industrial capitalism and the ensuant pauperization of broad social groups. In this context, anarchy was understood as describing the lack of predictability and internal cohesion of the capitalist economic system..$^{53}$ However, the interpretation which interests me the most in the present context, and which has already been mentioned during the analysis of Paris as the hotbed of anarchic infection, refers first and foremost to the lack of political and organizational unity on the part of the Polish diaspora. In this sense, the concept frequently functioned on two levels: by drawing justification from a reflection that was historiosophic in nature, individual groupings endowed it with specific meaning within the framework of current political disputes.

This was exactly how the concept of anarchy was employed by the Hotel Lambert milieu. While reflecting on the failure of the November Uprising, Czartoryski suggested that it was the radicals who were to blame

52 Żaliński, Poglądy Hotelu Lambert, p. 166.

${ }^{53}$ A number of inspiring analyses of how the Polish elites (including the emigrant elites) perceived industrialism in the nineteenth century were authored by, among others, Jerzy Jedlicki, 'Polskie nurty ideowe lat 1790-1863 wobec cywilizacji Zachodu', in Swojskość i cudzoziemszczyzna w dziejach kultury polskiej, ed. Zofia Stefanowska, Warsaw, 1973, pp. 186-231; idem, Jakiej cywilizacji Polacy potrzebują: Studia z dziejów idei i wyobraźni XIX wieku, Warsaw, 1988; idem, 'Les mirages de l'occident', in Mythes et symboles politiques en Europe centrale, ed. Chantal Delsol, Joanna Nowicki and Michel Maslowski, Paris, 2002, pp. 611-26. 
for the defeat of 1831 . He wrote that the Insurrection would have ended in victory if only political unity had been ensured throughout its course. But it was the radicals who had established opposition groups and openly criticized the decisions of the authorities. ${ }^{54}$ Janusz Woronicz, an activist, journalist and political theoretician, voiced the opinion that the danger of falling into the trap of the 'complete solution', that is anarchy, which renders polities defenceless to external invasion, was inherent to the nature of every republican system. ${ }^{55}$ These historical reflections of the aristocratic-liberal camp clearly impacted the way in which émigré life was understood. Karol Sienkiewicz stated in one of his texts that without a 'Polish Institution', that is an unquestioned, representative authority, 'the mission of the Emigration shall fall, as fell the country, for want of unity'. ${ }^{56}$

An analysis of the discourse conducted by the radical émigré left provides an interesting insight into the ambiguities and ambivalences which surrounded its understanding of anarchy. The group of Worcell's supporters who brought about a rift in the London Generality in 1834 proceeded to accuse the 'liberals' (having in mind mainly the moderate democrats) of introducing divisions and general chaos. The advocates of schism pointed out that unlike their political opponents, they did not support complete freedom of speech, for it was their intention 'to draw together, not to individualize'. ${ }^{57}$ Later in the same year, however, Worcell wrote a letter in which he explained the reasons for the split in the Generality and gave clear indications that the 'drawing together' would not be unconditional. He further pointed out that in its existing form the London Generality had not been cemented by any specific political idea, and first and foremost that it had not voiced its opposition to the political dominance of the aristocracy with sufficient strength.$^{58}$ In this

54 'gdyby kluby cudowne polskie czucie w wyraźną anarchię nie wprowadziły i tam gdzie sama ufność i braterstwo panować były powinny, nie rozsiały niezgodę, potwarz i nieufność' ('if only those clubs had not twisted the fine feeling of Polishness into anarchy, and had not there, where only trust and brotherhood should have reigned, sowed discord, calumny and mistrust'). Quoted from: Żaliński, Stracone szanse, pp. 60-61.

${ }^{55}$ Janusz Woronicz, Rzecz o monarchii i dynastyi w Polsce, Paris, 1839, p. 11.

${ }^{56}$ Karol Sienkiewicz, Emigracia w 1856 r., in Pisma Karola Sienkiewicza: Prace historyczne i polityczne, Paris, 1862, pp. 461-71 (p. 462).

57 ‘Odezwa Gminy Londyńskiej Emigrantów Polskich do emigracji polskiej', in Geneza Ludu Polskiego w Anglii: Materiały źródłowe, ed. Peter Brock, London, 1962, pp. 200-29 (pp. 205-06).

58 'zgodnego w swojej nienawiści do arystokracyi Ogółu dziś nie ma, jest tylko konsekwentna, ze swoją przeszłością stała w zasadach swych, lecz numerycznie dotąd mniej liczna Gmina, która wiarę swą polityczną, jak Eneasz bogi domowe, ze zburzo- 
iinterpretation, unity not based on any ideological binding medium is closer to anarchy than a division effected on the basis of ideological principles.

Some of the emigrants also saw worrying signs of anarchy in national political life. Reactions of this type were not frequent, especially if we take into consideration that during periods of important national revolts (such as in 1846) the emigration subordinated itself to the authority of activists from the Polish lands. But even in special circumstances, such as those of the January Uprising (1863-64), one could find among the émigrés people who criticized domestic policy using the concept of 'anarchy'. Czyński in his letter to Konstanty Zaleski hinted, not without some irony, that although the Uprising was in progress, the members of its military command were unable to reach agreement. 'I have received a letter from Kraków. Most unfortunately, there is considerable anarchy in the city - only six committees are quarrelling with each other.' And he added: 'the blood that is being spilled, and all the positive attempts being made shall not bring about the desired result if brothers of good will do not reject their own beliefs and prejudices and unite'. ${ }^{59}$ Once again, anarchy turned out to be that which rendered victory impossible.

Thus, the Polish émigrés after the November Uprising functioned under conditions and circumstances that were conducive to ideological redefinitions and divisions. The source of the 'pestilence' and 'anarchy' turned out to be Paris, however very soon also those emigrants who had settled in other cities were forced to take some stance on the faits accomplis in order to find their place on the ever more fragmented political scene and be able to formulate political arguments with which to oppose antagonists from other groupings. ${ }^{60}$ It comes as no surprise, therefore, that

nego ręką nieprzyjaciół i na łup anarchii oddanego Ogółu całą uniosła i zbiór różnorodnych żywiołów, nazwisko Ogółu sobie przywłaszczający, który żadną główną ideą w jedność spojonym nie jest' ('a Generality that would be unanimous in its hatred of the aristocracy is today lacking; indeed, there is only one, hitherto less numerous Commune that has been consistent and true to its past, which [Commune; translator's note] - similarly to Aeneas, who carried the Household Gods to Latium - removed its political faith intact from the Generality, which had been destroyed by the hands of enemies and laid open to anarchy, and thus saved it [the faith; translator's note] from a motley selection of elements that had appropriated the name of the Generality, which is presently not united into a cohesive whole by any leading idea'). A letter from Stanisław Worcell to Franciszek Stawiarski, 11 September 1834, Biblioteka Polska in Paris, MS 607, pp. 307-08.

${ }^{59}$ A letter from Jan Czyński to Konstanty Zaleski, 16 April 1863, Biblioteka Śląska w Katowicach, MS 371 IV/VII, cards 80-81.

${ }^{60}$ We should note here that another factor causing discord between the emigrants was the activity of Russian agents. The actual scale of this phenomenon still awaits in-depth research. 
this situation - typically uncharacteristic of Polish political life - led to the emergence of an increasing number of concepts for the unification of the émigré milieux.

\section{The Cure: Concepts of Unification}

A very important attempt at unifying the Polish emigrant community was made in 1837 with the establishment of the United Polish Emigration. The Union was set up in the wake of negotiations which had first commenced in $1834 ;{ }^{61}$ as we have already mentioned, its initiator was Lelewel. From the very beginning, however, it lacked the qualities of a cohesive political organization; rather, it constituted a kind of nebular coalition, which in effect turned out to be incapable not only of undertaking energetic activity, but even of conducting a democratic and undisputed election of its own authorities. This singular political body had a moderately democratic programme (although attempts were made to avoid usage of the word 'democracy'), which democrats from the Polish Democratic Society - due to its 'moderateness' - maliciously called 'half-measured' (juste milieu). In actual fact, however, this lack of specificity was intended, because the primary objective of the Union was simply to unify the emigration. But it soon transpired that attempts at building a political project based first and foremost on the principle of unification formed a vicious circle, and indeed strengthened the divisions existing among émigrés, while at the same time leading to ideological and personal disputes and a general lack of cohesion in the Union. As Leon Zienkowicz pointed out, this organization misunderstood the concept of democracy, and thus concentrated its efforts on bringing about a reconciliation of completely disparate political groups and concepts that was simply impossible to achieve. ${ }^{62}$ Interestingly, the Zjednoczenie (Unification) journal, which was published by one of the communes belonging to this peculiar grouping, argued that the main authority backing the whole political project - Lelewel - 'never explains his thoughts with sufficient clarity - what are his beliefs?'. It was

${ }^{61}$ A number of hitherto unpublished appeals for unification, written circa 1834, have been found in the Parisian archives by Goddeeris, La Grande Émigration polonaise en Belgique, pp. 296-97.

62 'Zjednoczenie przez błędne zasad demokratycznych pojęcie, zbyt niesforne ze sobą żywioły kojarzyć usiłuje - przeto prędzej czy później u całkiem przeciwnego myśli i tytułowi swemu stanąć musi kresu' ('Basing itself on a misconception of democratic principles, the Union is attempting to bring about the association of elements that are too unruly to coexist with each other - and thus shall, sooner or later, be forced to adopt thoughts and catchwords completely opposite to those which it currently espouses'). Quoted from Cygler, Zjednoczenie Emigracji Polskiej, p. 79. 
further added that each and every view formulated with reference to unquestioningly perceived authorities is something that must be avoided at all costs. ${ }^{63}$

For a few years the United Polish Emigration was unable to elect its own authorities, while the methods which it used to recruit new members had very little in common with its political principles. Some persons, for example Antoni Ostrowski, were enrolled in the organization more or less by accident, by signing a manifesto shown to them on some random occasion. Finally, once its influence plummeted (having reached its apogee around 1840), the Union was dissolved on 10 July 1846.

The Hotel Lambert grouping adopted a different strategy towards the 'anarchization' of the political life of the emigrant community. This stance was clearly influenced by the personal authority of Prince Czartoryski, whom some of his supporters proclaimed king de facto, considering him a person who by right of birth, social position and services was predestined to represent Poland on the international stage and to govern the country once it regained independence. Thus, they viewed a monarch as someone who would be capable of putting down political particularism. ${ }^{64}$ According to journalists who sided with the Prince, monarchic ideas - and specifically the concept of the 'complete monarchy', which would be based on the principles of order and obedience ${ }^{65}-$ gained strength amongst Poles following the last failed insurrection. Another of the strategies used consisted in enforcing a partial suppression of any discussion on the past, or at least challenging the sense of such a debate. In April 1833, the liberal-monarchic camp announced the principle of 'let us first be, and only then determine how we shall be', which was based on the belief that making any determinations as to the form of Poland's system of government before the country regained independence should be avoided, for it could result in unnecessary friction within the pro-independence movement. As Michał Czajkowski, a pro-independence activist, writer and poet, wrote in one of his letters, the objective was to avoid discouraging those who had different visions of the reborn country from participating in the uprising: 'from participating in the act those in the homeland who have various opinions as to the

63 ‘opinia mająca swe źródło w powadze przełożonych jest zawsze opinią fakcyjną, takiej opinii zawsze się strzec powinniśmy' ('an opinion founded in the prestige of one's superiors is always a factional opinion, and one that we should always strive to avoid'). Zjednoczenie, 11 March 1842, part 2, no. 29, p. 3.

${ }^{64}$ Henryk Żaliński, ‘Książę Adam Jerzy Czartoryski jako król Polski “de facto”, in idem, Kraj, emigracja, niepodległość: Studia i szkice, Cracow, 2006, pp. 121-30.

${ }^{65}$ Trzeci Maj, 10 December 1839, p. 1. 
future social and political form of society in Poland' ${ }^{\prime 6}$ Moreover, in accordance with this idea the very existence of 'parties' during the period of partitions was considered as unnecessary, or indeed harmful. ${ }^{67}$ The increasing divergences of opinion in Polish political life did not weaken the monarchists' faith in the approach. This was primarily so because Czartoryski was convinced that in certain extreme situations, which he compared to a fire in a house or the sinking of a ship, even political opponents would be ready to cooperate with each other. ${ }^{68}$

It is interesting to note that the concepts of unification put forward by the radical left were characterized by a considerable confusion of organizational, ideological and state-institutional order. This was a paradox, for at the ideological level the radicals declared that they intended to eradicate all vestiges of the political system of the old Commonwealth. A particularly interesting example of such a faction was the Commune of Le Havre of the United Polish Emigration, which some historians did not view as representative of the radical left of the Great Emigration exactly because of its unificationist programme. ${ }^{69}$ Nevertheless, in my opinion this group had all the traits of political thinking typical of, for example, the Communes of the Polish People, while possible separatist or unificationist tendencies do not in and of themselves appear to be of decisive importance for determining its position on the political scene. Although the Commune of Le Havre joined the Union, it withheld from signing its manifesto because it planned to act in accordance with its own principles. On 8 March 1841, the Commune's Secretary, Jan Skórzewski, sent a letter to the Union's Val-de-Grâce Commune, in which he informed that the journal published by the Commune of Le Havre would have as its mission bringing about the unification of the émigré milieux, however he simultaneously stressed that this could be achieved only after its representatives made some changes to their political thinking. And thus, the Zjednoczenie journal 'will dispel the prejudices and darkness which surround us, leading to the unification of the various parties of our emigration, for the malign effects of the lack of unity are so clearly making themselves felt'. This undertaking would succeed,

${ }^{66}$ A letter from Michał Czajkowski to Henryk Kamieński, 22 July 1840, BC, MS 5556/II, pp. 5-6.

${ }^{67}$ Żaliński, Poglądy Hotelu Lambert, pp. 60-64.

${ }^{68}$ Ibid., p. 102.

${ }^{69}$ It was not been mentioned by, for example, Gryzelda Missalowa, 'Francuski socjalizm utopijny i jego wpływ na polską myśl rewolucyjną w latach 1830-1848', in W stulecie Wiosny Ludów: 1848-1948, ed. Natalia Gąsiorowska, 5 vols, Warsaw, 1948-53, vol. 3: Wiosna Ludów w Europie, part 2: Zagadnienia ideologiczne, ed. Henryk Katz, Witold Łukaszewicz and Gryzelda Missalowa, 1951. 
because: 'the journal is not the creation of any authority, any coterie, but the work of a unified people who intend to regain our political existence, hitherto desecrated and destroyed by parties and their federalism, only through the unification of the entire émigré milieu and the establishment of a representative body therefor. Without a doubt, the most important institution of a free people is an organ of public opinion, and it is up to us make sure that our journal assumes this role'. ${ }^{70}$ Thus, the proposed Union was not to be an association or a party, but a progressive society based on evangelical principles - ones that were common, instinctive, and did not necessitate separateness of political action. According to this interpretation of progress, division had to give way to unity. ${ }^{71}$

A comparison of the ideas formed by the Union's Le Havre Commune and the Communes of the Polish People with reference to the concepts of 'anarchy' and 'unity' is most interesting. In 1841, the Communes of the Polish People exchanged a number of letters with Le Havre; these were published in the Zjednoczenie. The representatives of the former were convinced that their organizational structure was not an artificially constructed political entity, but that it reflected the mechanisms adopted by peasants in the Polish lands, who lived, worked and took decisions within similar communities. For this reason, according to representatives of the Communes, unification could only consist in other persons joining their organization. In consequence, therefore, the Commune of Le Havre's expression of goodwill and stated conviction that the two organizations shared common beliefs was interpreted by the Communes of the Polish People as a direct declaration of accession. ${ }^{72}$ The fact aroused opposition in Le Havre, for its activists concluded that by applying this approach the Communes were actually separating themselves from others and attempting to appropriate the evangelical principles of communocracy on an exclusive basis, whereas these formed part of the spirit of the age and thus could not belong to any single grouping. ${ }^{73}$

70 The Commune of Le Havre to the Commune of Val-de-Grâce, 8 March 1841, BC, MS 5334, p. 523.

71 'osobnictwo, wyłączność i rozdrobnienie ustępują miejsca Ogółowi, Zjednoczeniu, Społeczności' ('separateness, exclusiveness and fragmentation are replaced by the Community, Unity, Society'). Zjednoczenie, 17 June 1841, vol.1, p. 30.

${ }^{72}$ Lud polski w emigracji: 1835-1846, ed. Zenon Świętosławski, Jersey, 1854, p. 230.

${ }^{73}$ Zjednoczenie, 18 August 1841, vol. 1, pp. 46-47. 
The Relapses: Democracy and Unification

In the main, accusations of introducing anarchy to the emigrant milieu, whether formed by the advocates of 'half-measures' (juste milieu) or by followers of Czartoryski, or even by the radical left, were directed towards the avowed democrats, that is the Polish Democratic Society. It should not come as a surprise, therefore, that the leading journalists supporting this party frequently polemicized with such charges, pointing out that anarchy is a concept on the whole more closely connected with advocates of the old privileges, namely of the persons grouped around the person of Prince Czartoryski. Democrats moved the discussion on anarchy from the level of day-to-day political fighting to that of the system of government, for they perceived anarchy itself not as the lack of political unity, but rather as the result of the oppression of the majority of society by the minority. ${ }^{74}$ In his letter of 1834 , the democrat Kazimierz Tomkiewicz, while sharing with Janowski his reflections on the initial version of one of the more important Janowski's works - the Krótki katechizm polityczny (A Brief Political Catechism) - turned attention to the different definitions of anarchy functioning in the Polish and the French political discourse: 'The French use the term "anarchy" to describe the appropriation of power, and for them an anarchic government is one which does not follow from the general will [...] [we - P.K.] understand anarchy to mean the non-existence of any authority, that is the absence of government' ${ }^{75}$

Thus, the most important ideologues of the Polish Democratic Society - as opposed to many of their right-wing and left-wing opponents made a conscious effort in their writings to separate the issue of organization of political parties from a state-systemic reflection. In other words, they perceived the state as a form of institutional order that was not connected with individual political groupings. This allowed the democrats to transfer deliberations on the categories of unity and anarchy to a different level, for unlike many émigré parties they considered political fragmentation or disagreement as a natural (or even desired) element of the public sphere. Thus, they viewed anarchy not as discord, but as the lack of a capable central authority in the state.

Their interpretation was clear from the earliest beginnings of the Polish Democratic Society, as can be seen in its so-called Small Manifesto. Its

${ }^{74} \mathrm{Cf}$. the entry for 'Anarchia', in 'Krótki Słownik Polityczny do napisania: Projekt', BJ, MS 3670, pp. 4-6.

${ }^{75}$ A letter from Kazimierz Tomkiewicz to Jan Nepomucen Janowski, 24 January 1834, BJ, MS 3685, vol. 7, card 77. 
authors pointed out that the existence of different political groupings and opinions, as opposed to the establishment of associations grouped around influential personages, was both appropriate and natural for 'normal' societies. ${ }^{76}$ Their Great Manifesto, published in 1836 , contained the following unequivocal statement: 'We shall not offer our hand to those of different faiths, for it is contrary to our conscience to make concessions to anyone. We shall not sacrifice our political faith for the pretence of unity'. ${ }^{77} \mathrm{Janow}-$ ski even touched upon the issue in one of his poems, tellingly titled Mniemana bezstronność (Feigned Impartiality): 'Whosoever shall, because in public life / He is not a member of any grouping, / Present himself as impartial, judicious, practical, / Will not gain my trust, only that of the crowd' ${ }^{78} \mathrm{Ja}$ nowski was therefore of the opinion that participation in public life requires not only specific traits and qualities of character ('virtues'), but also a clear declaration as to whose side one is on in the on-going political debates. This did not mean, however, that the category of unity was absent from the democrats' discourse. To the contrary: it constituted an important part of their political thinking, although it was usually understood not as the simple unification of all émigrés, but rather as the coincidence of outlook of persons who shared the democrats' ideological standpoint. In 1837, the newly elected Central Authority wrote with enthusiasm about the state of the Polish Democratic Society: 'More than one thousand individuals display the desired unity, the prerequisite for political action. Unity has created a force - this force will give rise to a movement - and the movement shall bring us salvation!.... . $^{79}$

Towards the end of its long existence, however, the Polish Democratic Society helped initiate one of the most interesting and at the same time important unificationist initiatives in the history of the Great Emigration. This development was connected with the fact that the organization itself was experiencing increasing stagnation, for the 1850s were a period in which a great many émigré undertakings withered away. In 1860, the Society had no more than 300 members, nevertheless it continued to be the most numerous and tightly-knit grouping in the emigrant milieu. By the second half of the nineteenth century, a large number of clandestine plans

76 'Akt założenia Towarzystwa Demokratycznego Polskiego', in Towarzystwo Demokratyczne Polskie: Dokumenty i pisma, ed. Bronisław Baczko, Warsaw, 1954, pp. 1-8 (pp. 7-8).

77 'Manifest Towarzystwa Demokratycznego Polskiego', in Towarzystwo Demokratyczne Polskie, pp. 85-96 (p. 95).

78 'Ktokolwiek dla tego, że w życiu publicznym / Do żadnego z różnych stronnictw nie należy, / Mieni się bezstronnym, rozumnym, praktycznym, / Temu ja nie uwierzę, chociaż mu tłum wierzy', Jan N. Janowski, Mniemana bezstronność, BJ, MS 3661, card 51.

${ }^{79}$ Demokrata Polski, 5 December 1837, vol.1, p. 55. 
and attempts aimed at fomenting an uprising in Poland - all inspired by the exiles - had failed utterly, however the democrats remained determined to complete their mission and help the homeland regain control of its destiny. ${ }^{80}$ In 1861 , when the lands of the Russian partition became the scene of a 'moral revolution', which manifested itself in an intensification of patriotism and social involvement (this took various forms, from street demonstrations to efforts undertaken by peasants to gain some measure of influence in the election of lower-ranking village officials $)^{81}$, while the emigration increasingly became a "community of the elderly', ${ }^{82}$ the Central Authority in London was faced with the task of redefining the organizational structure of the Polish Democratic Society. At the time, however, separate projects of unification were being drawn up both by the democrats and Czartoryski's grouping. ${ }^{83}$ On 29 December 1861 in Paris, acting upon an initiative developed primarily by Janowski, Zienkowicz and Ludwik Bulewski, the exiles established the Temporary Committee of the Polish Emigration, which on 12 January 1862 issued a proclamation calling upon the émigrés to unite under the aegis of the democratically elected Committee of the Polish Emigration. It was further announced that the Polish Democratic Society would be dissolved following the election of members to this body. ${ }^{84}$

Interesting conclusions as to the degree of understanding of the tensions existing between 'anarchy' and 'unity' in emigrant circles may be drawn from an analysis of the copious body of letters sent in to the Temporary Committee of the Polish Emigration between January and May 1862. This correspondence presents a number of the practices employed by the democrat exiles of the time (as well as their perceptions of what such practices should consist in), and allows us to take a closer look at both the broad cross-section of arguments for unification, and the diversity of definitions of political anarchy. And because this exchange of letters was participated in not only by the leading personages of the émigré milieu, but also by many ordinary emigrants, who played no important role in the activities of contemporary political parties (some were even illiterate, and signed themselves with a cross),

${ }^{80}$ Helena Rzadkowska, Działalność Centralizacji Londyńskiej Towarzystwa Demokratycznego Polskiego 1850-1862, Wrocław, 1971, p. 111.

${ }^{81}$ Emanuel Halicz, Rola nurtu plebejskiego w polskich powstaniach narodowych XVIII i XIX, Warsaw, 1956, pp. 78, 122-23.

${ }^{82}$ A term coined by Alina Witkowska, Cześć i skandale: 0 emigracyjnym doświadczeniu Polaków, Gdańsk, 1997, p. 137.

${ }^{83}$ Helena Rzadkowska, 'Próby zjednoczenia emigracji w latach 1861-1863', Rocznik Naukowo-Dydaktyczny WSP w Krakowie, 32: Prace Historyczne, 4, 1968, pp. 183-210 (pp.186-87).

${ }^{84}$ Ibid., pp. 188-90. 
this material provides us with a significant insight into the political mentality of the Polish diaspora.

Numerous statements made by correspondents bring to light the paradox that was inherent in practically all unificationist concepts put forward by the émigrés, namely that of particularism masked with the rhetoric of universalism. For this reason, many letters simply affirm the idea of creating a 'democratic' Union, and such pronouncements are frequently accompanied by enthusiastic declarations of accession to the initiative.$^{85}$ The above notwithstanding, some correspondents were clearly critical of incorporating the adjective 'democratic' into the official documents of the Committee. ${ }^{86}$ Their authors often had an understanding of politics which differed from that of the democratic ideologues; for them, 'services' and 'virtues' were of decisive importance - not the fact of being skilled at convincing others to one's arguments in the course of discussions conducted in the public sphere. It is interesting to note, however, that the adoption of this universalistic perspective could lead not only to the rejection of the concept of democratic unification, but also to its affirmation. Namely, some of the correspondents stated that they were joining not a 'democratic', but a 'national' union, thereby considering as non-national everything that was non-democratic. ${ }^{87}$

Many of the authors of the letters sent in to the Temporary Committee of the Polish Emigration had an interesting way of speaking about the current state of the emigration, for example using religious rhetoric to compare the condition of its political fragmentation with 'sacrilege', or pointing out that divisions serve to paralyse the actions and aspirations of the emigration, for they are contrary to the principles of brotherhood. ${ }^{88}$ Another way of substantiating support for this initiative was through the belief that by dissolving itself and proposing in its stead a broader, more inclusive organizational format, the Polish Democratic Society was in actual fact fulfilling the will of those in the homeland, who in consequence of their patriotic actions had come to lead the cause of independence. Correspondents stressed that by undertaking the present initiative, the

${ }^{85}$ Cf. the following letters: dated 28 January (fol. 6), dated 30 January (fol. 7), dated 6 February (fol. 44), dated 10 February (fol. 57), dated 15 February (fol. 65), dated 15 February (fol. 69), dated 21 February (fol. 84), dated 11 March (fols 121-22) and dated 6 February (fol. 42), BJ, MS 3679.

${ }^{86} \mathrm{Cf}$. the letter dated 24 January (fols 2-5), BJ, MS 3679.

${ }^{87} \mathrm{Cf}$. the following letters: dated 9 February (fol. 38), dated 2 February (fol. 46) and dated 9 February (fol. 53), BJ, MS 3679.

${ }^{88} \mathrm{Cf}$. the following letters: undated (fol. 14), dated 3 March (fols 97-98) and dated 16 March (fols 155-56), BJ, MS 3679. 
Society was not establishing a new 'party' (in émigré circles this word had invariably negative connotations), ${ }^{89}$ although there were also quite a few sceptics who inquired why a new Committee was necessary if those in the homeland had taken over the helm. ${ }^{90}$ Sometimes, however, the reflection led to completely different conclusions, and a number of the writers appeared to criticize the apparent insufficient inclusiveness of the Committee, fearing that, when all was said and done, it would fail to function as a real representation of the émigrés. For this reason, certain of the correspondents demanded the option of voting (from the old Polish verb wotować - to express one's personal support for someone or something) for Władysław Czartoryski (the son of Adam Jerzy) or for supporters of Towiański. ${ }^{91}$ Probably the most sceptical opinion was put forward by Józef Jaczyński, who spoke on behalf of the centre in Beauvais; he stated that hitherto the concept of unification had not played a positive role in Polish history. He further observed that while it had been expressed at regional councils of the nobility and during the November Uprising, it had had absolutely no effect. ${ }^{92}$

Within this collection of correspondence we may find statements indicating that even some of the 'rank-and-file' democrats displayed the way of thinking, mentioned previously, which mixed the model of political organization with issues concerning the state and system of government. For example, one of the correspondents declared that the political system adopted by the émigré community following its unification should serve as the model for Poland's own system of government after it regained independence, and proposed the name 'Representation' instead of 'Committee'.$^{93}$ Another declared that elections to the Committee should be based on exactly the same principles as those to the national authorities. ${ }^{94}$ The reflection of the émigré poet Cyprian Kamil Norwid, who also decided to respond to the appeal, went in a completely different direction altogether.

${ }^{89}$ Cf. the following letters: dated 31 January (fol. 12), dated 2 February (fol. 17), dated 26 January (fols 31-34) and undated (fols 110-11), BJ, MS 3679.

${ }_{90} \mathrm{Cf}$. the letter dated 2 February (fols 17-18), BJ, MS 3679.

${ }^{91}$ Cf. the following letters: dated 13 March (fols 131-32), dated 13 March (fol. 139), dated 14 March (fol. 145) and dated 29 March (fols 178-79), BJ, MS 3679.

92 'Zjednoczenie smutną zajmuje kartę w naszej historii. Począwszy od sejmikowego "Zgodą, panowie bracia", które się skończyło na upadku naszego narodu; wykrzykiwano w pamiętnym powstaniu listopadowym: jedność, zgoda, ufność' ('Unification is a sad chapter of our history. Starting from the "Concord, my fellow brothers", which was voiced at regional councils and, tragically, led to the collapse of our nation, it progressed to the "unity" "harmony" and "trust" shouted out in the course of the eventful November Uprising'). Cf. the letter dated 21 February (fol. 83), BJ, MS 3679.

${ }^{93}$ Cf. the letter dated 2 February (fols 19-21), BJ, MS 3679.

${ }^{94} \mathrm{Cf}$. the letter dated 12 March (fols 129-30), BJ, MS 3679. 
Namely, he indicated that the public sphere in exile was too weakly developed, stating that 'it is impossible to organize a general vote and elections where there is no journalism and where elementary principles of openness [of public life - P.K.] do not exist, and where candidates cannot freely announce their programmes'. ${ }^{95}$

According to the final list presented at the end of the collection (incomplete, as the person who drew it up noted), 682 people voted for the Committee. ${ }^{96}$ However, Helena Rzadkowska, who conducted detailed research, estimates that the number of people who participated in elections to the Committee of the Polish Emigration totalled approximately $1,400 .^{97}$

Thus, the democrats gave different meanings to the categories of 'unity' and 'anarchy' than the other political parties of the Great Emigration, which were situated to their left and to their right. This dissimilarity has led certain researchers to conclude that the Polish Democratic Society should be recognized as the first modern Polish political party. ${ }^{98}$ I, however, am inclined to focus my deliberations not on affirming or refuting this thesis (this would, after all, necessitate the development of a theory of a model 'modern' party, which would clearly exceed the scope of the present study), but on bringing to light the distinctive features of the political thinking of the main ideologues of the Polish Democratic Society. First and foremost, this grouping was unique among émigré circles in that it remained convinced that a political organization and the state were two completely separate entities. In this sense, its members interpreted the concept of anarchy primarily on the level of the political system. What is more, the democrats considered that any 'unity' worthy of the name referred to the cohesion of an organization grouped around similar ideological principles. Thus, they proved themselves consistent when rejecting the émigré authorities (Bem, Czartoryski, Lelewel and others), whom they ultimately did not replace with other 'virtuous' or 'well-deserved' persons (in spite of a fleeting fascination with General Ludwik Mierosławski, the commander of the Uprisings of 1846 and 1848), but with ideas and principles. $^{99}$

${ }^{95}$ A letter from Cyprian Kamil Norwid, dated 8 March, BJ, MS 3679, fol. 115.

${ }^{96}$ BJ, MS 3679, fols 216-23.

${ }_{97}$ Rzadkowska, Próby zjednoczenia, p. 205.

${ }^{98}$ Sławomir Kalembka, Towarzystwo Demokratyczne Polskie w latach 1832-1846, Toruń, 1966, p. 261; Jarosław Tomasiewicz, Po dwakroć niepokorni: Szkice z dziejów polskiej lewicy patriotycznej, Łódź, 2014, p. 13.

${ }_{99}$ Nevertheless, it would be difficult to consider that the substitution of an attachment to persons with a purely ideological binding agent constitutes an indicator 


\section{Conclusions}

It would be a simplification to contend that all political emigrations finally undergo division and fragmentation, for at the theoretical level we may determine a few potential models of functioning of such communities. The first of these is complete unity of thought and action, which could be achieved and maintained solely if the period of exile was brief or was ideological in nature (for example repressions against sympathizers of a specific party). A different model would concern the division of émigré groupings into supporters of the most deserved and influential persons, however without any clear ideological criterion. The third type is based on a division of the emigration according to the ideological framework taken from its country of origin - a good example would be the French emigration to the United States in the wake of the Spring of Nations, which to a large extent reconstructed the division of France into 'red' and 'moderate' Republicans. ${ }^{100}$ The fourth and final model concerns the emergence within emigrant circles of new ideas which lead to polarization. Obviously, when dealing with political thinking it is rarely possible to ascertain the complete discontinuation of specific concepts and the creation of ones that are totally new. It would be difficult, however, not to consider the Russian revolutionaries at the turn of the twentieth century - to give but one example - using this criterion. ${ }^{101}$ First and foremost, the Great Emigration appears to connect the 'personal' model (Czartoryski's circle, Rybiński's and Towiański's) with that which consisted in the emergence of new ideological categories (the 'patent-holder' democrats). Nevertheless, the concepts of unity and cohesion continued to remain as a constant political point of reference irrespective of whether they were applied to persons 'from without' (Lelewel's United Polish Emigration, the Hotel Lambert), or to already dedicated members of specific organizations (Worcell with respect to the advocates of scission in the London Generality, the Polish Democratic Society). This conclusion is supported not only by the fact

of the 'modernity' of a political party. Suffice it to say that over the past few years a number of groupings or electoral lists which differ considerably from the model proposed by the Polish Democratic Society - to mention but 'Ruch Palikota', 'Kukiz'15' (both Poland), 'The Other Europe with Tsipras' (Greece), the 'List of Marjan Šarec', or the 'Party of Alenka Bratušek' (both Slovenia) - have appeared on the European political scene.

100 Michel Cordillot, Utopistes et exilés du Nouveau Monde: Des Français aux États-Unis de 1848 à la Commune, Paris, 2013.

${ }^{101}$ Numerous examples have been given in Helen Rappaport's Conspirator: Lenin in Exile, New York, 2010. 
that the concept of 'unity' was frequently mentioned in the contemporary political discourse, but also by the number of journals and actual undertakings that used this very word in their names.

On the whole, the Great Emigration appears automatically to generate positive connotations among Polish researchers, many of whom have pointed out that its capability of action was impeded by internal divisions. In concluding, and somewhat as a counter to these views, I would like to cite the opinion of Hans Henning Hahn, who as a German perforce approached the history of the post-November emigration without any specifically Polish emotional baggage. Hahn stated that without a permanent division of the émigré milieu it would have been impossible for it to achieve intellectual development, for the very simple reason that constant dispute fosters mental inquiry and reflection. ${ }^{102}$ This thread appears to be worthy of analysis, for the rifts appearing within emigrant circles and the concomitant 'hellish quarrels' were the main factors which stimulated the development of political argumentation, leading in a relatively short period of time to the considerable modernization of the Polish political imagination, even when compared to Western Europe. A good example here would be the concept of democracy: the Polish Democratic Society was the first organization in Europe to include this adjective in its name. Another example is the concept of 'socialism', which appeared in the Polish language already in 1834, and therefore somewhat earlier than in the German discourse ${ }^{103}$ and a good 30 years before it emerged in the Finnish. ${ }^{104}$ Thus, the public sphere in exile was a space within which modern political awareness developed a considerable time before the Polish lands underwent rapid industrialization and urbanization. It is, however, worth stressing that these developments were not specific to Poland alone - similar examples may be found in the previously mentioned experiences of Russian, and even Italian émigrés, who all made a significant contribution to the development of modern national concepts. ${ }^{105}$ It may therefore be that the discordant nineteenth-century exiles from the peripheries of Europe should actually be viewed

${ }^{102}$ Hans Henning Hahn, 'Möglichkeiten und Formen politischen Handelns in der Emigration: Ein historisch-systematischer Deutungsversuch am Beispiel des Exils in Europa nach 1830 und ein Plädoyer für eine international vergleichende Exilforschung', Archiv fur Sozialgeschichte, 23, 1983, pp.123-61 (p. 141).

${ }^{103}$ Marian Żychowski, Polska myśl socjalistyczna XIX i XX wieku, Warsaw, 1976, p. 11.

104 Wiktor Marzec and Risto Turunen, 'Socialisms in the Tsarist Borderlands: Poland and Finland in a Contrastive Comparison, 1830-1907', Contributions to the History of Concepts, 13, 2018, 2, pp. 22-50.

105 Ronald S. Cunsolo, 'Italian Emigration and Its Effect on the Rise of Nationalism', Italian Americana, 12, 1993, 1, pp. 62-72. 
as political experimenters and innovators, who thought in modern categories long before the politic systems, societies and economies of their countries of origin underwent far-reaching modernization.

(Translated by Maciej Zakrzewski)

\section{Summary}

The objective of the article is an examination of the mechanism which led to the appearance of the public sphere in the milieu of the Great Emigration, and also the presentation of an issue-based approach to the tensions which arose between 'unity' and 'anarchy' - the two categories closely connected with this mechanism. In the first part I have analysed the scale of Polish literary output and the dynamics of political life in the first years of the Emigration, juxtaposing them with the categories inherited from the Polish-Lithuanian Commonwealth. The second section discusses the Parisian 'anarchy' and the stance of Polish emigrant organizations (opposed to the democrats) towards the failure of attempts at providing the Emigration with authorities that would have been universally recognized by the exiles. In the third part I have undertaken an interpretation of the most important concepts of unity, put forward in the main by the milieu gathered around Prince Adam Jerzy Czartoryski (1770-1861) - the Minister of Foreign Affairs of the Russian Empire in the years 1804-06, the First Minister (President) of the National Government of the Kingdom of Poland in 1831, and the founder of the aristocratic-liberal camp. The concept of unity was, however, significant not only for supporters of the Prince, but also for the radical left (such as the Commune of Le Havre). The fourth and final part is concerned with an analysis of how the democrats approached the abovementioned pair of concepts, with particular focus on the attempt, made in 1862 , to unify the émigré milieux. In concluding, I have drawn attention to the long-term consequences of the discussed phenomena, first and foremost for the relatively early introduction of modern political notions (for example that of 'socialism') into the Polish language.

(Translated by Maciej Zakrzewski)

\section{Bibliography}

‘Akt założenia Towarzystwa Demokratycznego Polskiego', in Towarzystwo Demokratyczne Polskie: Dokumenty i pisma, ed. Bronisław Baczko, Warsaw: Książka i Wiedza, 1954, pp.1-8.

Asmus, Helmut, 'Trasy przemarszu wychodźców polskich po upadku powstania listopadowego przez państwa niemieckie do zachodniej Europy', Przeglad Humanistyczny, 26, 1982, 3/4, pp. 1-24.

Baár, Monika, Historians and Nationalism: East-Central Europe in the Nineteenth Century, Oxford: Oxford University Press, 2010. 
Baczko, Bronisław, Poglady społeczno-polityczne i filozoficzne Towarzystwa Demokratycznego Polskiego, Warsaw: Książka i Wiedza, 1955.

Bordet, Gaston, La Pologne, Lamennais et ses amis 1830-1834, Paris: Éditions du Dialogue: Centre National de la Recherche Scientifique, 1985.

Cordillot, Michel, Utopistes et exilés du Nouveau Monde: Des Français aux États-Unis de 1848 à la Commune, Paris: Vendémiaire, 2013.

Cunsolo, Ronald S., 'Italian Emigration and Its Effect on the Rise of Nationalism', Italian Americana, 12, 1993, 1, pp. 62-72.

Cygler, Bogusław, 'Obchody rocznic wybuchu powstania listopadowego na emigracji do 1846 roku', in Powstanie czy rewolucja? W 150 rocznice powstania listopadowego, ed. Henryk Kocój, Katowice: Uniwersytet Śląski, 1981, pp. 287-308.

Cygler, Bogusław, Zjednoczenie Emigracji Polskiej 1837-1846, Gdańsk: Wyższa Szkoła Pedagogiczna w Gdańsku, 1963.

Czyński, Jan, Józef Kozłowski, Paris: [n. pub.], 1832.

Dziennik Bibianny Moraczewskiej, ed. Ludwika Dobrzyńska-Rybicka, Poznań: Chocieszyński, 1911.

Fraser, Nancy, 'Rethinking the Public Sphere: A Contribution to the Critique of Actually Existing Democracy', Social Text, 1990, 25/26, pp. 56-80.

Gadon, Lubomir, Emigracya Polska: Pierwsze lata po upadku powstania listopadowego, 3 vols, Cracow: Spółka Wydawnicza Polska, 1901-02, vol. 1.

Goddeeris, Idesbald, La Grande Émigration polonaise en Belgique (1831-1870): Élites et masses en exil à l'époque romantique, Frankfurt am Main: Peter Lang, 2013.

Grześkowiak-Krwawicz, Anna, 'Anti-monarchism in Polish Republicanism in the Seventeenth and Eighteenth Centuries', in Republicanism: A Shared European Heritage, ed. Marin van Gelderen and Quentin Skinner, 2 vols, Cambridge: Cambridge University Press, 2002, vol. 1: Republicanism and Constitutionalism in Early Modern Europe, pp. 43-60.

Grześkowiak-Krwawicz, Anna, 'Spór o “Ustawę rządową” jako zderzenie dwóch dyskursów politycznych?’, Wiek Oświecenia, 31, 2015, pp. 195-212.

Hahn, Hans Henning, 'Möglichkeiten und Formen politischen Handelns in der Emigration: Ein historisch-systematischer Deutungsversuch am Beispiel des Exils in Europa nach 1830 und ein Plädoyer für eine international vergleichende Exilforschung', Archiv fur Sozialgeschichte, 23, 1983, pp. 123-61.

Halicz, Emanuel, Rola nurtu plebejskiego w polskich powstaniach narodowych XVIII i XIX, Warsaw: Wydawnictwo Ministerstwa Obrony Narodowej, 1956.

Janion, Maria, ‘Estetyka średniowiecznej północy’, in Maria Janion, Prace wybrane, 5 vols, ed. Małgorzata Czermińska, Cracow: Towarzystwo Autorów i Wydawców Prac Naukowych 'Universitas', 2000-02, vol. 4: Romantyzm i jego media, 2001, pp. 7-88.

Janowski, Jan Nepomucen, Notatki autobiograficzne 1803-1853, ed. Marian Tyrowicz, Wrocław: Wydawnictwo Zakładu Narodowego im. Ossolińskich, 1950. Janowski, Maciej, 'Rozpacz oświeconych? Przemiana polskiego języka politycznego a reakcje na upadek Rzeczypospolitej’, Wiek Oświecenia, 25, 2009, pp. 29-60. Jasienica, Paweł, Polska anarchia, Warsaw: Prószyński i S-ka, 2008. 
Jedlicki, Jerzy, Jakiej cywilizacji Polacy potrzebują: Studia z dziejów idei i wyobraźni XIX wieku, Warsaw: Państwowe Wydawnictwo Naukowe, 1988.

Jedlicki, Jerzy, Les mirages de l'occident, in Mythes et symboles politiques en Europe centrale, ed. Chantal Delsol, Joanna Nowicki and Michel Maslowski, Paris: Editions du Cerf, 2002, pp. 611-26.

Jedlicki, Jerzy, 'Polskie nurty ideowe lat 1790-1863 wobec cywilizacji Zachodu', in Swojskość i cudzoziemszczyzna w dziejach kultury polskiej, ed. Zofia Stefanowska, Warsaw: Państwowe Wydawnictwo Naukowe, 1973, pp. 186-231.

Józefczyk, Andrzej, Wspomnienie ubiegłych lat (Przyczynek do Historyi Spisków w Galicyi), Cracow: 'Przegląd Polski', 1881.

Kalembka, Sławomir, Prasa demokratyczna Wielkiej Emigracji: Dzieje i główne koncepcje polityczne (1832-1863), Toruń: Uniwersytet Mikołaja Kopernika, 1977.

Kalembka, Sławomir, Towarzystwo Demokratyczne Polskie w latach 1832-1846, Poznań: Państwowe Wydawnictwo Naukowe; Toruń: Towarzystwo Naukowe w Toruniu, 1966.

Kalembka, Sławomir, Wielka Emigracja: Polskie wychodźstwo polityczne w latach 1831-1862, Warsaw: Wiedza Powszechna, 1971.

Karpińska, Małgorzata, 'Sejm polski na emigracji 1832-1848: Problemy i pytania badawcze', in Wokót powstania listopadowego: Zbiór studiów, ed. Hubert Chudzio and Janusz Pezda, Cracow: Polska Akademia Umiejętności, 2014, pp. 291-307.

Kasparek, Norbert, Powstańczy epilog: Żołnierze listopadowi w dniach klęski i internowania 1831-1832, Olsztyn: Wydawnictwo Uniwersytetu Warmińsko-Mazurskiego, 2001.

Kolasa, Władysław Marek, 'Prasa Wielkiej Emigracji (1832-1870) w polskim prasoznawstwie', Zeszyty Prasoznawcze, 56, 2013, 3, pp. 389-400.

Koselleck, Reinhart, Kritik und Krise: Eine Studie zur Pathogenese der bürgerlichen Welt, Frankfurt am Main: Suhrkamp, 1973.

Koselleck, Reinhart, 'Zur historisch-politischen Semantik asymmetrischer Gegenbegriffe', in Reinhart Koselleck, Vergangene Zukunft: Zur Semantik geschichtlicher Zeiten, Frankfurt am Main: Suhrkamp, 1995, pp. 211-59.

Królikowski, Ludwik, Do panślawistów: pogłos z odwiedzin niby sławiańskich w Moskwie 1867 roku, part 1, Zurich: [n. pub.], 1868-74.

Kucharzewski, Jan, Maurycy Mochnacki, Cracow: Gebethner i Spółka; Warsaw: Gebethner i Wolff, 1910.

Lelewel, Joachim, Dzieje Polski potocznym sposobem opowiedziane, ed. Janina Bieniarz, Warsaw: Państwowe Wydawnictwo Naukowe, 1961.

Lewak, Adam, 'Czasy Wielkiej Emigracji', in Polska, jej dzieje i kultura, ed. Stanisław Lam, 3 vols, Cracow: Trzaska, Evert i Michalski, [1929-32], vol. 3, pp. 193-233.

Limanowski, Bolesław, Stanisław Worcell: Życiorys, Warsaw: Spółdzielnia Wydawnicza 'Wiedza', 1948.

Listy emigracyjne Joachima Lelewela, ed. Helena Więckowska, 5 vols, Cracow: Polska Akademia Umiejętności, 1948-56, vol. 1: 1831-1835 (Nry 1-289).

Lud polski w emigracji: 1835-1846, ed. Zenon Świętosławski, Jersey: [n. pub.], 1854. 
Łukaszewicz, Witold, Stanisław Gabriel Worcell, Warsaw: Wydawnictwo Ministerstwa Obrony Narodowej, 1951.

'Manifest Towarzystwa Demokratycznego Polskiego', in Towarzystwo Demokratyczne Polskie: Dokumenty i pisma, ed. Bronisław Baczko, Warsaw: Książka i Wiedza, 1954, pp. 85-96.

Marchlewicz, Krzysztof, Wielka Emigracja na Wyspach Brytyjskich (1831-1863), Poznań: Instytut Historii UAM, 2008.

Marzec, Wiktor, and Kamil Śmiechowski, 'Pathogenesis of the Polish Public Sphere: The Intelligentsia and Popular Unrest during and after the $1905 \mathrm{Re}$ volution', Polish Sociological Review, 2016, 4 (196), pp. 437-57.

Marzec, Wiktor, and Risto Turunen, 'Socialisms in the Tsarist Borderlands: Poland and Finland in a Contrastive Comparison, 1830-1907', Contributions to the History of Concepts, 13, 2018, 2, pp. 22-50.

Milbach, Sylvain, 'Perspectives catholiques sur la révolution: L'Avenir de Lamennais', in Quand les socialistes inventaient l'avenir: Presse, théories et expériences, 1825-1860, ed. Thomas Bouchet et al., Paris: La Découverte, 2015, pp. 62-74.

Missalowa, Gryzelda, 'Francuski socjalizm utopijny i jego wpływ na polską myśl rewolucyjną w latach 1830-1848', in W stulecie Wiosny Ludów: 1848-1948, ed. Natalia Gąsiorowska, 5 vols, Warsaw: Państwowy Instytut Wydawniczy, 1948-53, vol. 3: Wiosna Ludów w Europie, part 2: Zagadnienia ideologiczne, ed. Henryk Katz, Witold Łukaszewicz and Gryzelda Missalowa, 1951.

Mochnacki, Maurycy, Do Rodaków bawiacych w Paryżu przeciw Komitetowi Tymczasowemu Emigracji Polskiej, Paris: [n. pub.], 1831.

‘Odezwa Gminy Londyńskiej Emigrantów Polskich do emigracji polskiej', in Geneza Ludu Polskiego w Anglii: Materiały źródłowe, ed. Peter Brock, London: Świderski, 1962, pp. 200-29.

Perru, Olivier, 'Le concept d'association et l'unité politique: Étude critique chez Saint-Simon, Fourier et Marx', Philosophiques, 26, 1999, 1, pp. 83-108.

'Przemówienie Tadeusza Krępowieckiego, wygłoszone w Paryżu 29 listopada 1832 r. w rocznicę rewolucji polskiej', in Witold Łukaszewicz, Tadeusz Krępowiecki: Żołnierz rewolucjonista [1798-1847], Warsaw: Wydawnictwo Ministerstwa Obrony Narodowej, 1954, pp. 148-62.

Rappaport, Helen, Conspirator: Lenin in Exile, New York: ReadHowYouWant.com, 2010.

Rzadkowska, Helena, Działalność Centralizacji Londyńskiej Towarzystwa Demokratycznego Polskiego 1850-1862, Wrocław: Zakład Narodowy im. Ossolińskich, 1971.

Rzadkowska, Helena, ‘Próby zjednoczenia emigracji w latach 1861-1863', Rocznik Naukowo-Dydaktyczny WSP w Krakowie, 32: Prace Historyczne, 4, 1968, pp. 183-210. Sewell, Jr., William H., A Rhetoric of Bourgeois Revolution: The Abbé Sieyes and 'What is the Third Estate?', Durham, NC: Duke University Press, 1994.

Sienkiewicz, Karol, Emigracia w 1856 r., in Pisma Karola Sienkiewicza: Prace historyczne i polityczne, Paris: [n. pub.] 1862, pp. 461-71.

Sowa, Jan, Fantomowe ciało króla: Peryferyjne zmagania z nowoczesna forma, Cracow: Towarzystwo Autorów i Wydawców Prac Naukowych ‘Universitas', 2011. 
Tomasiewicz, Jarosław, Po dwakroć niepokorni: Szkice z dziejów polskiej lewicy patriotycznej, Łódź: Stowarzyszenie 'Obywatele Obywatelom', 2014.

Trencsényi, Balázs, 'Conceptual History and Political Languages: On the Central-European Adaptation of the Contextualist-Conceptualist Methodologies of Intellectual History', in The History of East-Central Europe and Russia, ed. Petr Roubal and Václav Veber, Prague: National Library of the Czech Republic, Slavonic Library, 2004, pp. 142-63, Prague Perspectives, vol. 1.

Trencsényi, Balázs, and Márton Zászkaliczky, 'Towards an Intellectual History of Patriotism in East Central Europe in the Early Modern Period', in Whose Love of Which Country? Composite States, National Histories and Patriotic Discourses in Early Modern East Central Europe, ed. Balázs Trencsényi and Márton Zászkaliczky, Leiden and Boston: Brill, 2010, pp. 1-72.

Trencsényi, Balázs, et al., A History of Modern Political Thought in East Central Europe, 2 vols, New York: Oxford University Press, 2016-18, vol. 1: Negotiating Modernity in the 'Long Nineteenth Century'.

Tyrowicz, Marian, Towarzystwo Demokratyczne Polskie, 1832-1863: Przywódcy i kadry członkowskie: Przewodnik biobibliograficzny, Warsaw: Książka i Wiedza, 1964.

Walicki, Andrzej, Philosophy and Romantic Nationalism: The Case of Poland, Oxford: Clarendon Press, 1982.

Witkowska, Alina, Cześć i skandale: 0 emigracyjnym doświadczeniu Polaków, Gdańsk: Słowo/obraz terytoria, 1997.

Witkowska, Alina, Wielkie stulecie Polaków, Warsaw: Państwowe Wydawnictwo Naukowe, 1987.

Woronicz, Janusz, Rzecz o monarchii i dynastyi w Polsce, Paris: [n. pub.], 1839.

Zajewski, Władysław, Walki wewnętrzne ugrupowań politycznych w powstaniu listopadowym 1830-1831, Gdańsk: Gdańskie Towarzystwo Naukowe, 1967.

Zwierkowski, Walenty, O Sejmie w emigracyi, Poitiers: [n. pub.], 1839.

Żaliński, Henryk, 'Książę Adam Jerzy Czartoryski jako król Polski “de facto"', in Henryk Żaliński, Kraj, emigracja, niepodległość: Studia i szkice, Cracow: Wydawnictwo Naukowe Akademii Pedagogicznej, 2006, pp. 121-30.

Żaliński, Henryk, Poglady Hotelu Lambert na ksztatt powstania zbrojnego (1832-1846), Cracow: Wydawnictwo Naukowe WSP, 1990.

Żaliński, Henryk, Stracone szanse: Wielka Emigracja o powstaniu listopadowym, Warsaw: Wydawnictwo Ministerstwa Obrony Narodowej, 1982.

Żychowski, Marian, Polska myśl socjalistyczna XIX i XX wieku, Warsaw: Państwowe Wydawnictwo Naukowe, 1976.

Bi ogra phy: Piotr Kuligowski - a doctoral student at the Department of Political Thought and Culture of the Institute of History of the Adam Mickiewicz University in Poznań, and visiting PhD student at the Centre de recherche en histoire européenne comparée of the Université Paris-Est Créteil. Research interests: nineteenth-century history, history of ideas and political ideologies, methodology of history. Editor of the Praktyka Teoretyczna journal. E-mail: piotr.kuligowski.1990@gmail,com. 